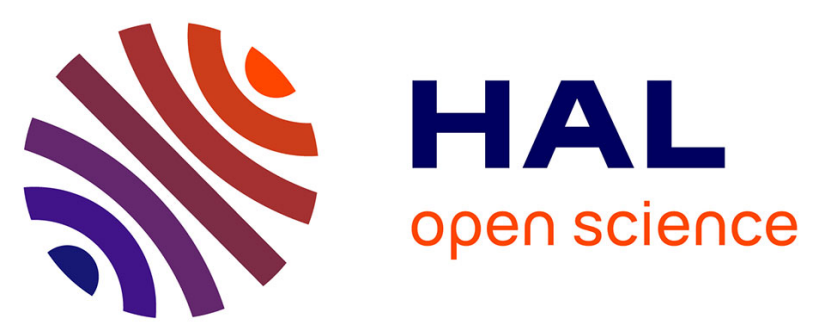

\title{
PRELIMINARY STUDY OF ORDER-DISORDER REACTION IN A Ni3 Fe0.76Al0.24 ALLOY BY MEANS OF ATOM-PROBE TECHNIQUES
}

D. Blavette, S. Chambreland

\section{- To cite this version:}

D. Blavette, S. Chambreland. PRELIMINARY STUDY OF ORDER-DISORDER REACTION IN A Ni3 Fe0.76Al0.24 ALLOY BY MEANS OF ATOM-PROBE TECHNIQUES. Journal de Physique Colloques, 1986, 47 (C2), pp.C2-227-C2-232. 10.1051/jphyscol:1986234 . jpa-00225667

\section{HAL Id: jpa-00225667 https://hal.science/jpa-00225667}

Submitted on 1 Jan 1986

HAL is a multi-disciplinary open access archive for the deposit and dissemination of scientific research documents, whether they are published or not. The documents may come from teaching and research institutions in France or abroad, or from public or private research centers.
L'archive ouverte pluridisciplinaire HAL, est destinée au dépôt et à la diffusion de documents scientifiques de niveau recherche, publiés ou non, émanant des établissements d'enseignement et de recherche français ou étrangers, des laboratoires publics ou privés. 
JOURNAL DE PHYSIQUE

Colloque C2, supplément au $\mathrm{n}^{\circ} 3$, Tome 47, mars 1986

page $\mathrm{C} 2-227$ PRELIMINARY STUDY OF ORDER-DISORDER REACTION IN A $\mathbf{N} \dot{I}_{3} \mathbf{F e}_{0.76} \mathbf{A l}_{0.24}$
ALLOY BY MEANS OF ATOM-PROBE TECHNIQUES

\author{
D. BLAVETTE and S. CHAMBRELAND
}

Laboratoire de Microscopie IOnique, UA CNRS 808, UER Sciences de Rouen, BP 67, F-76130 Mont-Saint-Aignan, France

Résumé - L'étude de la mise en ordre dans un alliage $\mathrm{Ni}_{3} \mathrm{Fe}_{0.76}{ }^{\mathrm{Al}} 0.24$ a été entreprise à l'aide d'une sonde atomique. L'analyse des plans (001) de surstructure de 1'alliage monophasé met en évidence 1 'alternance de plans mixtes $(50 \% \mathrm{Ni}, 50 \% \mathrm{Fe}, \mathrm{Al})$ avec des plans purs de $\mathrm{Ni}$. Une rupture de séquence dans 1 'empilement de ces plans a été observée et reliée à 1 'existence d'une paroj d'antiphase entre domaines ordonnés.

La composition des phases existant à plus hautes températures a pu être déterminêe en dépit de la faible différence de composition entre précipités et matrice et de la faible taille des particules.

Abstract - Atom study of ordering in a Ni $\mathrm{Fe}_{0.76} \mathrm{Al}_{0.24}$ has been undertaken. Analyses of the (001) superstructure planes of the one phase alloy exhibit the alternation of mixed planes ( $50 \% \mathrm{Ni}, 50 \% \mathrm{Al}, \mathrm{Fe}$ ) with pure planes $(100 \% \mathrm{Ni})$. A rupture of this stacking sequence was observed and has been correlated to the occurence of an antiphase boundary between ordered domains.

Composition of phases existing at higher temperatures has been determined in spite of the weak difference between matrix and precipitate composition and the small particle size.

\title{
I - INTRODUCTION
}

Although the study of ordering reactions in ternary alloys is of interest, few investigations have been performed on this subject.

Many years ago, Wakelin et al /1/ pointed out that addition of aluminium in $\mathrm{Ni}_{3} \mathrm{Fe}$ alloys increases the transition temperature. More recently, F. Bley /2/ investigated the role of $\mathrm{Al}$ in the kinetics of transformation in $\mathrm{Ni}_{3} \mathrm{Fe} \mathrm{Al}$ alloy and confirmed that the $\mathrm{LI}_{2}$ ordered structure is stabilized by aluminium. However, experiments showed that diffusion of $\mathrm{Ni}$ or $\mathrm{Fe}$ atoms is not influenced by small additions of aluminium. Moreover the author founded the growth rate of ordered domains to decrease with increasing aluminium concentrations and suggested that this slackening may be due to some solute segregation at antiphase boundaries. We now report a preliminary study of the microstructure and long range order in a $\mathrm{Ni}_{3} \mathrm{Fe}_{0.76}$ $\mathrm{A}_{0.24}$ by using atom probe techniques.

\section{II - EXPERIMENTAL}

The instrument details can be found elsewere /3/. Most of experiments were performed using a standard pulse fraction of $20 \%$ of the $D$. C. voltage and in a vacuum of $10^{-9}$ Torr. Tips were cooled at liquid nitrogen temperature.

Specimens were analysed for three various heat treatments taken under the transition temperature $\left(687^{\circ} \mathrm{C} / 1 \mathrm{~h} 30,542^{\circ} \mathrm{C} / 1300 \mathrm{~h}, 480^{\circ} \mathrm{C} / 118 \mathrm{~h}\right)$. The transition temperature of the ordered alloy $\mathrm{Ni}_{3} \mathrm{Fe} A 7$ is $\mathrm{T}_{\mathrm{C}}=746^{\circ} \mathrm{C}$ for 6 at $\% \mathrm{Al}$. At high temperatures below 
$T_{C}$, the microstructure consists in little spherical precipitates having a $\mathrm{LI}_{2}$ ordered structure $(100-500 \AA)$ finely dispersed in a FCC solid solution. For decreasing temperatures, the volume fraction increases and the particle shape becomes more and more irregular. Below $600^{\circ} \mathrm{C}$ the alloy is finally composed of adjacent ordered domains with sizes from 50 to few hundred Angströms.

\section{III - RESULTS}

Preliminary investigations have been carried out in order to find proper operating conditions required for quantitative analys is of these alloys.

The most important problem which occurs when analysing nickel base alloys is preferential evaporation. Figure 1 illustrates this phenomenon. The apparent composition is plotted versus the puise

fraction.

It is clear that the actual composition is not reached for pulse values lower than $15 \%$ of the $D C$ voltage. It is thought that preferential evaporation of nickel atoms is caused by field adsorption of hydrogen at the tip surface. It is indeed well known that chemisorption of hydrogen strongly reduces the evaporation field of nickel atoms. A mass spectrum of the alloy obtained with a pulse fraction of $20 \%$ is given figure 2 . Although expected compositions are measured in this case, difficulties were often encoun-

Fig. 1 - Apparent concentrations as a function of the pulse fraction $F$.

tered when analysing near low index planes because of the

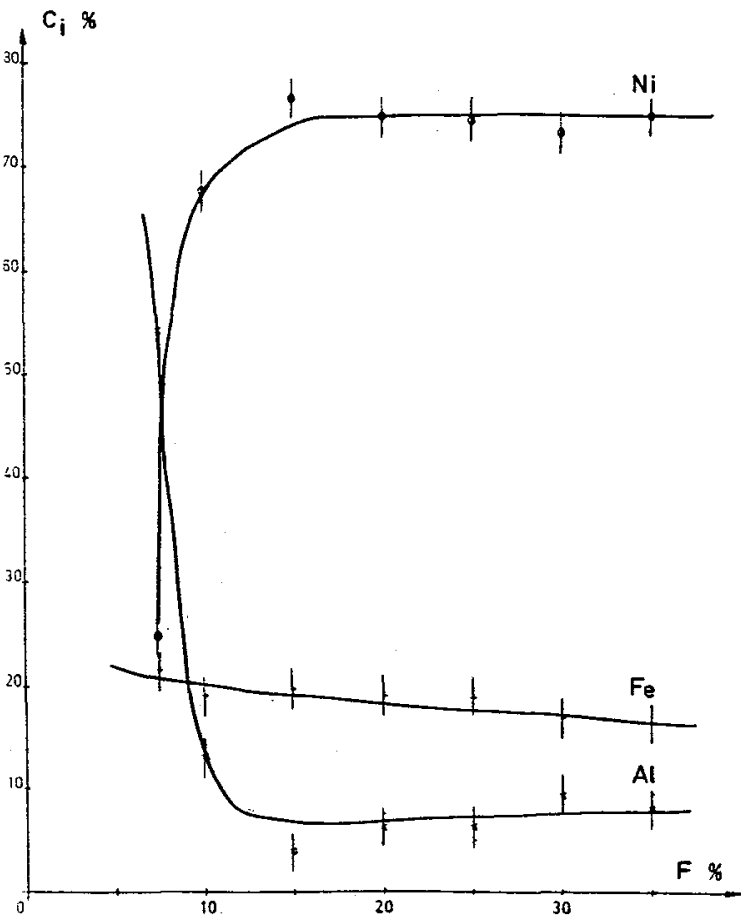
occurence of pronounced isotopic effects (pile-up of two or more ions).

We have made some experiments on (111) fundamental planes in order to investigate the field evaporation of surface atoms. Figure 3 shows a composition profile. The cumulative number of $\mathrm{Al}, \mathrm{Fe}$ or $\mathrm{Ni}$ is plotted versus the total number of detected ions. The end of each evaporating plane (dashed 1 ines) was determined from the flux modulations. The results exhibit that $A 1$ then Fe atoms are desorbed first while $\mathrm{Ni}$ atoms rather evaporate upon the completion of a plane collapse. This observation is somewhat surprising keeping in mind that nickel usually preferentially evaporates. However, as surface diffusion of molecules is easier on closely packed planes, hydrogen should be less stable on the (111) planes than on the others at $T=77 \mathrm{~K} / 4 /$. Therefore, the evaporation should be no longer promoted by chemisorption of $\mathrm{H}_{2}$ on these planes for this temperature. As $\mathrm{Al}$ and $\mathrm{Fe}$ have a smaller evaporation field than $\mathrm{Ni}$ in absence of $\mathrm{H}_{2}$, those species are expected to 
evaporate first on the (111) hydrogen free planes. This explanation is supported by the fact that neither hydrogen nor hydrides was detected during such analyses.
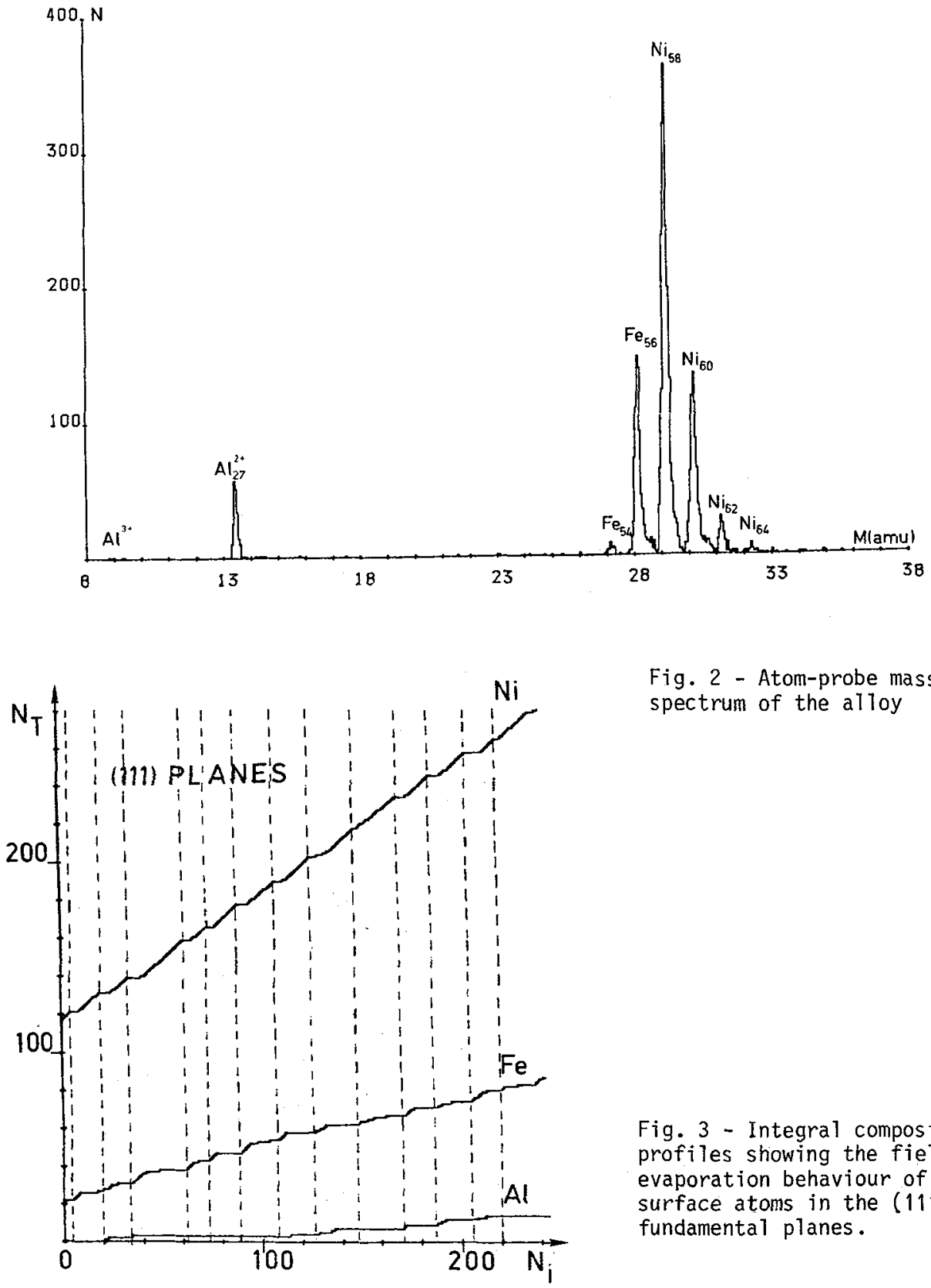

Fig. 2 - Atom-probe mass spectrum of the alloy

Fig. 3 - Integral composition profiles showing the field evaporation behaviour of surface atoms in the (111) fundamental planes. 
Quantitative analyses of (001) superlattice planes of the one phase $\mathrm{Ni}_{3} \mathrm{Fe}_{0.76} \mathrm{Al}_{0.24}$ a $110 y\left(480^{\circ} \mathrm{C} / 118 \mathrm{~h}\right)$ have been carried out $/ 5 /$. Composition profiles are shown figure 4 and exhibit the expected alternation of mixed planes ( $50 \% \mathrm{Ni}, 50 \% \mathrm{Al} \mathrm{Fe})$ with pureplanes $(100 \% \mathrm{Ni})$. Fe atoms were sometimes found to substitute to $\mathrm{Ni}$ atoms in the $\mathrm{L}_{2}$ ordered structure. Low evaporation rates (100 pulses/ion) were used in order to prevent detection artifacts from interfering. An interesting phenomenon may readily be observed in the figure 4 : the ordered sequence of $(001)$ planes is altered within few layers in the middle of the profile. As the size of ordered domains is $100 \AA$, we think that this sequence rupture is connected with an antiphase boundary. The analys is direction is probably not perpendicular to the boundary in this case because the transition zone observed is broad.

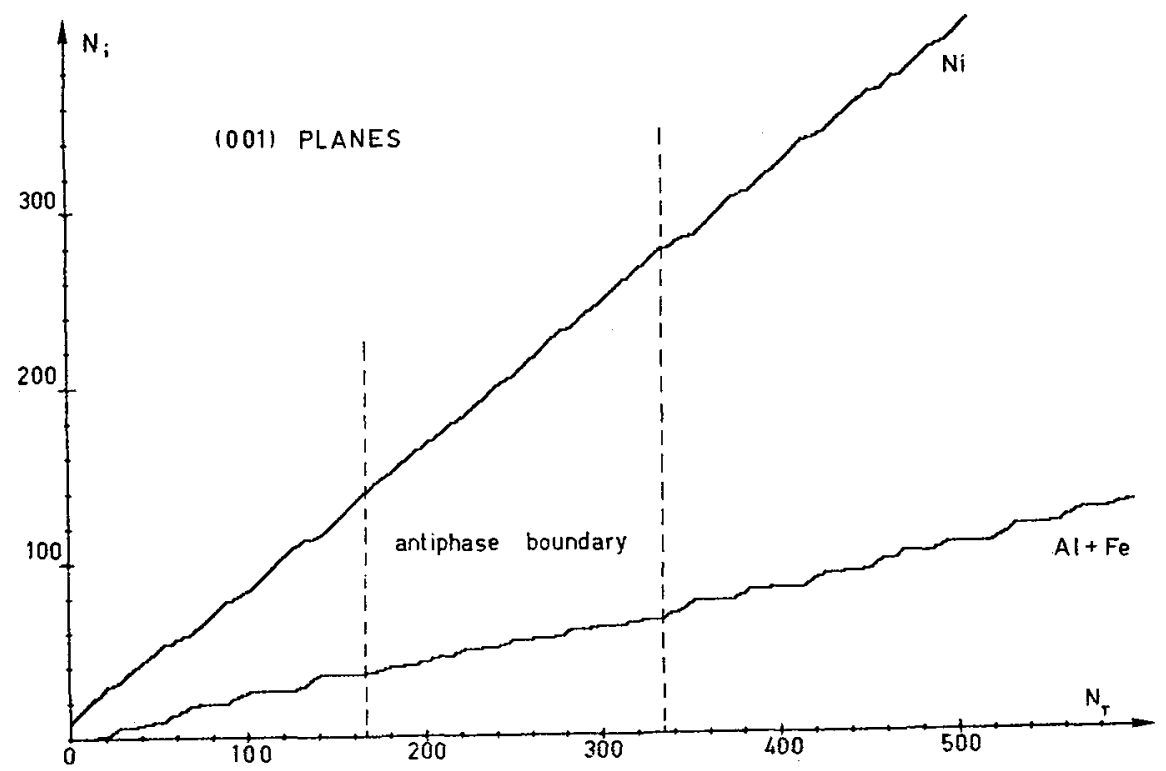

Fig. 4 - Integral composition profiles showing the alternation of (001) superstructure planes. The cumulative number of $\mathrm{Ni}$ or $\mathrm{Al}+\mathrm{Fe}$ is plotted versus the total number of detected ions

Among the results we obtained, no visible enhancement in solute concentration could be detected at the boundary. Al segregation does not seem to be responsible here of the observed slackening of the domain growth.

Random area investigations of the alloy, heat treated at higher temperatures $\left(687^{\circ} \mathrm{C} / 1 \mathrm{~h} 30\right)$ have been achieved in order to get phase composition. A field ion micrograph is shown figure 5 . Four particules having sizes of few hundred angströms appear in bright contrast while the surrounded matrix remains dark. Low index poles are also visible.

The measured compositions of both phases are summarized in figure 6 . The aluminium concentration is plotted against the chromium one for precipitates and matrix analyses respectively. As the alloy has the stoichiometric composition and precipitates have an ordered structure based on $\mathrm{Ni}_{3}$ (Fe, Al) all the measured compositions must lie on a straight line with a slope equal to unity $\left(\mathrm{C}_{\mathrm{Al}}=25-\mathrm{C}_{\mathrm{Fe}}\right)$. 

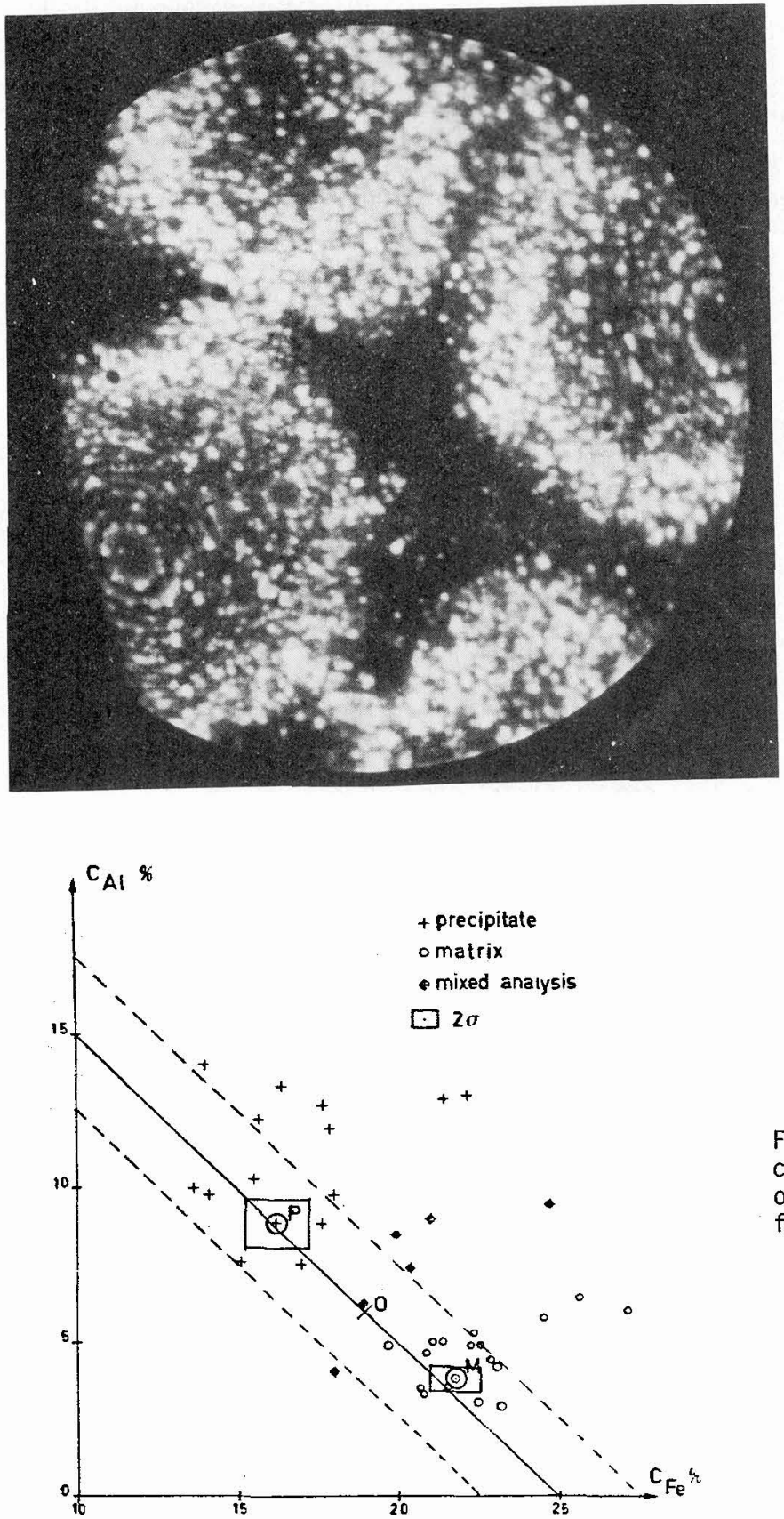

Fig. 5 - Field ion micrograph of the two phase alloy. Four particles are brightly imaged
Fig. 6 - Measured AT

concentrations as a fonction of observed Fe concentrations for matrix and precipitates

Because of statistical fluctuations all points does not necessarily fall on this straight line. The mean standard deviation for precipitates ( $N \cong 400$ atoms) is indicated by two parallel dashed lines. Some measurements are located outside of these lines because preferential evaporation occured. As phase composition are 
close $(5 \%)$, It was sometimes difficult to detect the precipitate presence or even to decide where phase boundaries are in composition profiles, especially when little particules were crossed on a edge. The diagramm shown figure 6 exhibits very clearly those analyses for which such a situation occurs. The points corresponding to "mixed" analyses are located somewhere between the mean composition of particules $(P)$ and the matrix one $(M)$. These data have not been taken into account in the averaged compositions $M$ and $P$. The fact that point $O$ (nominal composition) is aligned with $M$ and $P$ proves that atom-probe data are consistent. Moreover the volume fraction of precipitates can readily be estimated from this diagram $\left(f:=\frac{O M}{P M} \cong 47 \%\right)$.

\section{Acknowledgements}

The $\mathrm{Ni}_{3}$ Fe Al wires were kindly supplied by $\mathrm{F}$. Bley (Ecole de Chimie de Grenoble). The authors wish to thank her for many fruitful discussions.

\section{REFERENCES}

/1/ Wakelin, R. J. and Yates, E. L., Proc. Phys. Soc., B66 (1953) 221

/2/ Bley, F., Thesis (1975) Paris

13/ Sarrau, J. M., Gallot, J., Avene1, 0., Roubeau, P., J. Phys. E : Sci. Instr. 14 (1981) 800

/4/ Nishikawa, T., Yoshimura, T., Shibata, M., Surf. Sci. 133 (1983) 15

/5/ Blavette, D., Menand, A., CRAS t. 298-II (1984) 865 